\title{
Managing multi-generation employees at work: understanding inter-generational employee differences with big-five models and their effects on job stress
}

\author{
Diaz Haryokusumo ${ }^{1}$ and Bambang Setia Wibowo² \\ ${ }^{1,2}$ Management Department, STIE YKPN School of Business, Indonesia
}

\begin{abstract}
This study aims to determine differences of employee's personality between generation $\mathrm{X}$ and generation $\mathrm{Y}$. We use the big five personality model consists of extraversion, agreableness, conscientiousness, neoriticsm, and openness to experience. This research also intended to examine the effect of big five personality on job stress on generation $X$ and $Y$. The hypothesis was tested using independent sample t-test and multiple regression. The results of hypothesis testing on 126 samples indicated that there are no personality differences in the big five dimension among generation $X$ and $Y$. The multiple regression results also do not show the influence of personality types on the level of work stress felt by generation $\mathrm{X}$ and $\mathrm{Y}$. Additional analysis results show there is no difference in job stress level felt by generation $X$ and $Y$.
\end{abstract}

\section{INTRODUCTION}

In recent years, there has been an increase of popular literatures which focuses on discussing the importance of understanding, managing, bonding, and providing different treatments between generation $Y$ and $X$ among employees (Wong, Gardiner, Lang, \& Coulon, 2008). This proliferation arises based on the awareness that there are fundamental differences in work values and personality characteristics across generations. A failure to overcome these differences can lead to workplace conflicts, misunderstandings, and make employee productivity suffer (Smola \& Sutton, 2002; Yu \& Miller, 2003).

Truxillo, McCune, Bertolino, \& Fraccalori (2012) also highlight several important reasons for understanding the differences in the nature of employees that exist between generations: (1) the increasing number of employees from generation $X$ and generation $Y$ that begins to enter the workplace; (2) various research results show there are groups of employees based on generation at work (e.g. Smola \& Sutton, 2002; Twenge \& Campbell, 2008, Wong, Gardiner, Lang, \& Coulon, 2008; Lyons \&Kuron, 2014); (3) possible differences such as individual differences in different generations have not been tested empirically. Therefore, it is important to understand the individual differences among generation $X$ and $Y$ in the workplace.

In Indonesia, managers todays also dealing with phenomenon of multigenerations employee. According to study by Yasmina in Fajriyati (2012), workforce profile of Indonesian companies consist of three generations; the baby boomers, generation $X$ and generation $\mathrm{Y}$. Therefore, our study objectives are to examine whether there are differences of big five personality (extraversion, agreeableness, conscientiousness, neuroticism, openness to experience) among generation $X$ and $Y$ in Indonesian workforce. Furthermore, our study also examine the effect of big five personality on job stress on generation $\mathrm{X}$ and $\mathrm{Y}$.

According to Riggio (2003) job stress is a physiological and/or psychological reaction to an event assessed by someone as a threat. Evan and Johnson (2000) state that job stress is a factor that determines the ups and downs of employee performance. Job stress causes deviations in psychological, physical and individual behaviors that cause deviations from normal functions (Beehr \& Newman, 1988; Robbins, 2004). 


\section{LITERATURE REVIEW AND HYPOTHESES DEVELOPMENT}

\section{Level of extraversion between generation $X$ and generation $Y$}

Someone who has a high extraversion is characterized by being sociable, active, gregarious, and talkative (Costa \& McRae, 1992b). While its characteristic opponents, namely people who tend to be introverted, tend to be often restrained and independent. The aspects that form extraversion are friendliness, perseverance, optimism, activity, seeking excitement, and joy (Goldberg et al., 2006). From the meta-analysis study Roberts and colleagues (2006), that the increasing age of a person, will increase the extraversion aspect in the form of social domination (optimism), and at the same time decreases social vitality (activity level).

Wood and Robert (2006) argue that in general extraversion will decrease with age, in line with previous findings (e.g. Levin, 1988) which states that the more age increases, it is seen as less active and energetic. From this description, we expect that generation $X$ employees have extraversion scores lower than generation $\mathrm{Y}$.

H1a: There are differences in the level of extraversion between generation $X$ and $Y$ among employees.

\section{Level of agreeableness between generation $X$ and generation $Y$}

Agreeableness has characteristics of sincerity in sharing, subtlety of feelings, focusing on positive things in others, altuis, and sympathy (Ramadhani, 2012; Goldberg et al., 2006). Individuals with high levels of agreeableness tend to be gentle, kind, helpful, trustworthy, easy to forgive, easy to use, and continue (Hardiyanti, 2013; Costa \& McRae, 1992b). Along with age, Roberts et al. (2006) found there was an increase in the level of agreeableness in a person. Wood and Roberts (2006) suggest that people in the age role have more agreeableness. Similar to previous findings (Cuddy \& Fiske, 2002), a senior person is considered better and wiser. Therefore, we have the notion that generation $X$ employees have a higher level of agreeableness than generation $\mathrm{Y}$.
H1b: There are differences in the level of agreeableness between generation $X$ and $Y$ among employees.

\section{Level of conscientiousness between generation $X$ and generation $Y$}

Individuals who are strong in conscientiousness tend to be goal-directed, strong-willed, and determined. They also tend to be more thorough and reliable (Costa \& McRae, 1992b, in Truxillo et al., 2012). Aspects in the conscientiousness dimension include self-efficacy, regularity, perseverance, struggle for results, and discipline (Goldberg et al., 2006). The metaanalysis from Roberts, Walton, and Viechtbauer (2006) states that the level of conscientiousness can increase with age, although the increase varies in various aspects.

Study conducted by Wood and Roberts (2006) showed that conscientiousness was found to be higher in older people. In a review of research by Posthuma and Campion (2009) stated that older workers were seen as more reliable. This is in line with previous research proposed by Rosen and Jerdee (1976) which states that senior employees are seen as more reliable. In general, we predict that generation $X$ will have a higher level of conscientiousness than generation $\mathrm{X}$, although for certain aspects, for example achievement may have a lower score than generation $X$ because senior employees are less active and energetic.

H1c There are differences in the level of conscientiousness between generation $X$ and $Y$ among employees.

\section{Level of neuroticism between generation $X$ and generation $Y$}

Neuroticism is the opposite of emotional stability. This trait is often characterized by worry, tension, and fear (Ramdhani, 2012; Goldberg et al., 2006). A person with a high level of neuroticism tends to feel negative emotions such as fear and shame (Costa \& McCrae, 1992b; McCrae \& John, 1992). Based on changes and development of age, Roberts et al. (2006) found that age will increase along with increasing emotional stability. Wood and Roberts (2006) also found that in old age, dimensions of emotional stability were higher. We have the notion that $X$ generation employees will be 
more emotionally stable and have lower levels of neuroticism than generation $\mathrm{Y}$.

H1d: There are differences in the level of neuroticism between generation $X$ and $Y$ among employees.

\section{Level of openness to experience between generation $X$ and generation $Y$}

Individuals with high openness to experience are described as having high curiosity, broad interest, creative, original, and imaginative (Hardiyanti, 2013). Aydogmus (2016) states that generation $\mathrm{Y}$ tend to have innovative ideas and they are easily mastering new technologies. Alexander and Sysko (2012) state that a common factor that causes generation $Y$ to resign and find new jobs is to expect a more challenging and self-fulfilling job, which is closely related to innovative attitudes and intelligence.

The results of a study from Truxillo et al. (2012) concluded that young generation employees have a higher level of openness to experience than the older generation, especially scores on dimensions of imagination, emotionality, adventurousness, and liberalism. We have therefore suggest the following hypothesis.

H1e: There are differences in the level of openness to experience between generation $X$ and $Y$ among employees.

\section{Extraversion and work stress}

Someone who has a high extraversion is characterized by being sociable, active, gregarious, and talkative (Costa \& McRae, 1992b). Individuals with these personality traits tend to show positive emotions and has high intensity of social communication. Extravert individuals also have high optimism (Watson \& Clark, 1992), and this leads them to always view the positive side of their experiences. In addition, extravert individuals often use strategies to deal with problems rationally, have positive judgments, have good problem solving skills, and search for social support (Dorn \& Matthews, 1992; Watson \& Hubbard, 1996). From the description above, we suggest that someone with extraversion personality will negatively affect work stress.

H2a: Extraversion personality has negative effect on work stress.

\section{Agreeableness and work stress}

Agreeableness is characterized by sincerity in sharing, subtlety of feelings, focus on positive things in others, altuis, and sympathy (Ramdhani, 2012; Goldberget al., 2006). Individuals with high levels of agreeableness tend to be gentle, kind, helpful, trustworthy and forgiving (Hardiyanti, 2013; Costa \& McRae, 1992b). In addition, someone with this personality is characterized by an altruistic person. Research shows that this personality type is negatively related to mental fatigue, burnout, and depersonalization (Deary et al., 1996; Zellars et al., 2000). Based on description above, we suggest that agreeableness has a negative effect on work stress.

H2b: Agreeableness personality has negative effect on work stress.

\section{Conscientiousness and work stress}

Individuals who are strong in conscientiousness tend to be goal-directed, strong-willed, and determined. They also tend to be more thorough and reliable (Costa \& McRae, 1992b, in Truxilloet al., 2012). Some facets in the conscientiousness dimension include self-efficacy, regularity, perseverance, struggle for results, and discipline (Goldberget al., 2006). Researchers (for example, Watson \& Hubbard, 1996) associate these personalities with problem-solving abilities because they have high persistence. In addition, Costa, McCrae, and Dye (1991) associate conscientiousness with discipline, willingness to fight, perseverance, and high competence. Persistence and discipline are thought to cause someone with this personality type to have high desires in completing tasks and doing positive performance. We have therefore suggest the following hypothesis.

H2c: Conscientiousness personality has negative effect on work stress.

\section{Neuroticism and work stress}

A person with high levels of neuroticism often feels negative emotions such as fear and shame (Costa \& McCrae, 1992b; McCrae \& John, 1992). Some studies (Lingard, 2003; Zellars et al., 2000) show that these individuals often experience mental fatigue. 
Furthermore, a person with a high neuroticism score is also found to often experience burnout in work and has a low desire for performance or achievement. From this description, researchers suspect that someone with a neuroticism personality will experience work stress.

H2d: Neuroticism personality has positive effect on work stress.

\section{Openness to experience and work stress}

Openness to experience is a personality that has a high curiosity, broad interest, creative, original, imaginative, not outdated (Hardiyanti, 2013). This personality is able to overcome problems in a short time, limited information, and high uncertainty (McAdams \& Pals, 2006; Denissen \& Penke, 2008), which is caused by having many bright ideas (Ashton \& Lee, 2007). Researchers suspect, because these individuals have high creativity in completing tasks and jobs, they are not susceptible to experiencing job stress.

H2e: Openness to experience personality has positive effect on work stress.

\section{METHODS}

The design of this study is a survey method with a questionnaire as a tool for collecting data. The type of data is cross-sectional, with data collection methods using self-administered surveys. We processed 126 respondents with varied backgrounds including from banking, health, education, manufacturing, and services.

Validity test of measurements in this study used the pearson's product moment correlation. The test results showed that from all measuremenst items, only one statement item for measuring the level of agreeableness, item $A 3$, which shows a probability value $>0.05(p$-value $=0.322)$ indicating that the indicator does not have a significant correlation with the average score agreeableness. Based on this, scale item A3 dropped and not used in the next process.

Reliability test conducted using cronbach's alpha by including indicators that have been considered valid in testing validity. Table 1 presents the results of the reliability test for all variables in this study.
Table 1.

Reliability Test

\begin{tabular}{lcc}
\hline Variables & $\begin{array}{c}\text { Total } \\
\text { Items }\end{array}$ & $\begin{array}{c}\text { Cronbach's } \\
\text { Alpha }\end{array}$ \\
\hline Extraversion & 8 & 0,761 \\
Agreeableness & 8 & 0,726 \\
Conscientiousness & 9 & 0,821 \\
Neuroticism & 8 & 0,773 \\
Openness to & 10 & 0,744 \\
Experience & 10 & 0,915 \\
Work Stress & 10 \\
\hline
\end{tabular}

To test the differences in personality of generation $X$ and $Y$, the independent sample t-test was conducted. Hypotheses testing for the influence of personality on work stress with multiple regression. Comparative tests of variance for the effect of personality on work stress based on generation are done with one-way ANOVA.

All items were measured on Likert-type scales from 1 (strongly disagree) to 5 (strongly agree). Because all items originally developed in English and intended for use in Indonesia context, we did translation and back-translation method. Personality variables measured with the Big Five Inventory (BFI) developed by John, Donahue, and Knetle (1991). The measuring instrument consists of 44 items, consisting of eight statement items each to measure neuroticism ( $N$ ) and extraversion (E), nine items each to measure conscientiousness (C) and agreeableness (A), and 10 items to measure openness to experience $(\mathrm{O})$. One example of a statement item for each personality dimension is, (I see myself as someone who...) "worries a lot" and "get nervous easily" for neuroticism; "comes up with new ideas" and "is curious about many different things" for openness to experience, "full of energy" and "tend to be quiet" for extraversion; "is helpful and unselfish with others" and "like to cooperates with others" for agreeableness; "is easily to distracted" and "does things efficiently" for conscientiousness. Job stress was measured with tenitems adapted from Parker and DeCotiis (1983). Sample items include, "Working here makes it difficult to enjoy time with family" and "I feel like I have never had a day off".

\section{RESULTS AND DISCUSSION}

126 questionnaires were processed in our study and majority of generation $X$ and $Y$ respondents were women $(57.1 \%$ and $54.9 \%)$. The most marital status for 
generation $X$ and $Y$ is married $(97.1 \%$ and $60.4 \%)$. The generation $X$ education level is dominated by master degree (45.7\%) while the majority of generation $Y$ education is undergraduate level (41.8\%). The majority of generation $X$ respondents have a tenure of more than 10 years (94.3\%) and for generation $\mathrm{y}$ are dominated with a working period of $1-5$ years (85.7\%).

To test hypotheses 1a-1e, we performed a t-test (table 2). To test the hypothesis of the personality effect on job stress (hypotheses 2a-2e), we used multiple regression (table 3). Comparative tests of variance the influence of personality to job stress based on generation were carried out with one-way ANOVA (table 4).

Before making a decision through the ttest, we conducted a test of variance similarity (homogeneity) with an F-test (Lavene's test) for generation differences (generation $X$ and $Y$ ) with all dimensions of the big five. The results show the same variance ( $p>0.05)$, so researchers use Equal Variance Assumed.

The independent sample t-test results shown in table 2 for testing hypotheses $1 \mathrm{a}$, $1 \mathrm{~b}, 1 \mathrm{c}, 1 \mathrm{~d}$, and 1e are described as follows. For hypothesis 1a, there is no difference in the level of extraversion between generation $X$ and generation $Y(t=-0.062 ; p>0.05)$. Therefore hypothesis $1 \mathrm{a}$ is not supported. For hypothesis $1 b$, there is no difference in the level of agreeableness between generation $x$ and generation y $\quad(t=0.816 ; \quad p>0.05)$. Therefore hypothesis $1 \mathrm{~b}$ is not supported. Hypothesis 1c states that there are differences in the level of conscientiousness in generations $x$ and $y$. The results of the $t$ test show that there is no difference between the two generations $(\mathrm{t}=1.778 ; \mathrm{p}>0.05)$. Therefore hypothesis $1 \mathrm{c}$ is not supported. For hypothesis $1 \mathrm{~d}$, there is no difference in the level of neuroticism between generation $x$ and generation y $(\mathrm{t}=-1.527 ; \mathrm{p}>0.05)$. Therefore hypothesis $1 \mathrm{~d}$ is not supported. Furthermore, for hypothesis $1 \mathrm{e}$, there is no difference in the level of openness to experience between generation $x$ and generation y $(t=1.075 ; p>0.05)$. Therefore hypothesis $1 \mathrm{e}$ is not supported.

The multiple regression results in table 3 are intended to test hypotheses $2 \mathrm{a}, 2 \mathrm{~b}, 2 \mathrm{c}$, $2 \mathrm{~d}$, and $2 \mathrm{e}$. From the results of the probability value (p-value) it can be seen that all probability values show values above 0.05 , so that hypotheses $2 \mathrm{a}, 2 \mathrm{~b}, 2 \mathrm{c}, 2 \mathrm{~d}$, and $2 \mathrm{e}$ are rejected. It can be concluded that extraversion, agreeableness, conscientiousness, and openness to experience do not negatively affect work stress (rejecting hypotheses 2a, 2b, 2c, and 2e), and neuroticism does not have a positive effect on work stress (rejecting hypothesis 2d).

We conducted additional analysis to find out whether there were differrences in the level of work stress experienced by generation $x$ and $y$ employees (table 4). From the results of the t-test by comparing the average work stress values of the two generations, there was no difference in the level of work stress felt by employees of generation $x$ and $y(t=-1,744 ; p>0.05)$.

Table 2.

T-Test Results for the BIG FIVE Sub-Factor Value of Generation X and Generation Y

\begin{tabular}{|c|c|c|c|c|c|c|c|c|}
\hline \multirow{2}{*}{ Variables } & \multirow{2}{*}{ Gen. } & \multirow{2}{*}{ Mean } & \multirow{2}{*}{ S.D. } & & \multicolumn{2}{|c|}{ Levene's test } & \multirow{2}{*}{$t$} & \multirow{2}{*}{$\begin{array}{c}\text { Sig. } \\
\text { (2-tailed) }\end{array}$} \\
\hline & & & & & $F$ & Sig. & & \\
\hline \multirow{3}{*}{ Extraversion } & Gen-X & 3,65 & ,56644 & Equal & \multirow[b]{2}{*}{0,641} & \multirow[b]{2}{*}{0,425} & \multirow[b]{2}{*}{$-0,062$} & \multirow[b]{2}{*}{0,951} \\
\hline & Gen-Y & 3,66 & ,58223 & $\begin{array}{l}\text { variances } \\
\text { assumed }\end{array}$ & & & & \\
\hline & Gen-X & 4,09 & ,43204 & Equal & \multirow[b]{2}{*}{3,466} & \multirow[b]{2}{*}{0,065} & \multirow[b]{2}{*}{0,816} & \multirow[b]{2}{*}{0,416} \\
\hline Agreeableness & Gen-Y & 4,01 & ,55766 & $\begin{array}{l}\text { variances } \\
\text { assumed }\end{array}$ & & & & \\
\hline \multirow[b]{2}{*}{ Conscientiousness } & Gen-X & 3,92 &, 50672 & Equal & \multirow[b]{2}{*}{2,942} & \multirow[b]{2}{*}{0,089} & \multirow[b]{2}{*}{1,778} & \multirow[b]{2}{*}{0,078} \\
\hline & Gen-Y & 3,71 & ,61443 & $\begin{array}{l}\text { variances } \\
\text { assumed }\end{array}$ & & & & \\
\hline \multirow[b]{2}{*}{ Neuroticism } & Gen-X & 2,46 & ,54719 & Equal & \multirow[b]{2}{*}{0,641} & \multirow[b]{2}{*}{0,498} & \multirow[b]{2}{*}{$-1,527$} & \multirow[b]{2}{*}{0,129} \\
\hline & Gen-Y & 2,64 & ,63672 & $\begin{array}{l}\text { variances } \\
\text { assumed }\end{array}$ & & & & \\
\hline \multirow{2}{*}{$\begin{array}{l}\text { Opennes to } \\
\text { Experience }\end{array}$} & Gen-X & 3,58 & , 52959 & Equal & \multirow[b]{2}{*}{2,460} & \multirow[b]{2}{*}{0,119} & \multirow[b]{2}{*}{1,075} & \multirow[b]{2}{*}{0,284} \\
\hline & Gen-Y & 3,48 & ,41013 & $\begin{array}{l}\text { variances } \\
\text { assumed }\end{array}$ & & & & \\
\hline
\end{tabular}


Table 3.

The Effects of Big Five Personality on Job Stress

\begin{tabular}{lccc}
\hline \multicolumn{1}{c}{ Independent Variable } & Standardized Coefficient & Standard Error & $\boldsymbol{P}$ \\
\hline Extraversion &,- 238 &, 164 &, 053 \\
Agreeableness &,- 041 &, 220 &, 791 \\
Conscientiousness &,- 170 &, 188 &, 247 \\
Neuroticism &, 144 &, 165 &, 279 \\
Opennes to Experience &, 070 &, 208 &, 517 \\
\hline
\end{tabular}

Table 4.

T-Test Results for Work Stress Value between Generation $X$ and Generation $Y$

\begin{tabular}{|c|c|c|c|c|c|c|}
\hline \multirow{2}{*}{ Group } & \multirow{2}{*}{$\begin{array}{c}\text { Mean of } \\
\text { Job Stress }\end{array}$} & \multirow{2}{*}{ S.D. } & \multicolumn{2}{|c|}{ Levene's Test } & \multirow{2}{*}{$t$} & \multirow{2}{*}{$\begin{array}{c}\text { Sig. } \\
\text { (2-tailed) }\end{array}$} \\
\hline & & & $\mathbf{F}$ & Sig. & & \\
\hline $\begin{array}{l}\text { Generation } X \\
\text { Generation } Y\end{array}$ & $\begin{array}{l}2,32 \\
2.59\end{array}$ & $\begin{array}{l}0,724 \\
0,791\end{array}$ & 1,046 & 0,308 & $-1,744$ & 0,084 \\
\hline
\end{tabular}

Based on the results of hypothesis testing, it can be concluded that there are no differrences in big five personality types (openness to experience, conscientiousness, extraversion, agreeableness, and neuroticcism) in generation $\mathrm{X}$ and generation $\mathrm{Y}$. Furthermore, there is no significant effect between big five personality types with job stress felt by both generation $\mathrm{X}$ and $\mathrm{Y}$. Based on additional analysi, it can be concluded that there is no difference in the level of job stress felt by generation $\mathrm{X}$ and $\mathrm{Y}$.

There are several alternative theories that can be used to explain the results of this research. In our initial explanation at the introduction, we agree with Smola and Sutton (2002), who argue that it is unavoidable to recognize that people who are born in the same time span have common influential experiences that lead to similarviews and values. As a consequence, such life experiences are what tend to distinguish one generation from another. This view is often referred to as generational cohort theory (Smola \& Sutton, 2002).

On the other hand, there are two theories that are contrary to generational cohort theory: "the cusp effect" and "the crossover effect" (Arsenault, 2004; Schewe \& Noble, 2000). The cusp effect refers to people born at the beginning and end of generations, so called "on the cusp". These people also often called as "tweeners". Therefore, these "tweeners" might have the same defining and memorable events in their lives as one generation, but are categorized into adifferent generational cohort according to their birth year (Arsenault, 2004).
The crossover effect, defined by Schewe and Noble (2000), describes the assumption that very significant events (e.g. John F. Kennedy's assassination or the Challenger incident) effect everyone, no matter what generation they belong to (Schewe \& Noble, 2000). Although some researchers may say that these two effect slead away from generational differences, the author of this article agrees with Arsenault (2004), who states that these effects can be used positively to demonstrate that there are similarities between different generations. These two theories is supported by the study from Kraus (2017). His study result said that the result of his theoretical part demonstrate an increasing tendency of similarities between generation $x$ and $y$ with respect to work factors and work values.

\section{CONCLUSION}

In this study, respondents conducted a selfreport, this has the potential to produce a common method bias. Future research can do several methods to control this bias such as with several steps in procedural improvement and statistical improvement. This study data collection was only carried out with surveys through questionnaires.

Exploration of respondents' information is very limited because they are unable to find further information about the respondents. To add a wealth of information and additional knowledge when compiling research results, further research can be enriched with insight from the results of interviews. In the next study, it can include the potential effects of mediation or moderation and make it possible 
to see the impact on big five personality types with other work attitudes.

\section{REFERENCES}

Alexander, C. S., \& Sysko, J. M. 2012. A study of the cognitive determinants of generation Y"s entitlement mentality. Academy of Educational Leadership Journal, 6(2): 6368.

Arsenault, P. M. 2004. Validating generational differences: A legitimate diversity and leadership issue. Leadership \& Organization Development Journal, 25(2): 124-141.

Ashton, M. C., \& Lee, K. 2007. Empirical, Theoretical, and Practical Advantages of the HEXACO Model of Personality Structure. Personality and Social Psychology Review, 11: 150-166.

Aydogmus, Ceren. 2016. How to Satisfy Generation Y? The Roles of Personality and Emotional Intelligence. International Review of Management and Business Research, 5 (4): 1342-1358.

Beehr, T. A., \& Newman, J. E. 1988. Psychological Stress In The Workplace. London: Routledge.

Cascio, W. F. 2013. Managing Human Resources (9th ed.). USA: McGraw-Hill.

Couper, Donald. R., \& Schlinder, Pamela. S. 2011. Business Research Method. New York: McGraw-Hill.

Costa, M. S., \& McRae, R. R. 1992a. Four Ways the Five Factors Are Basic. Personality and Individual Differences, 13: 653-665.

Costa, M. S., \& McRae, R. R. 1992b. NEO PI-R: Professional manual. Revised NEO Personality Inventory NEO PR-R and NEO Five-Factor Inventory NEO-RRI. Odessa, FL: Psychological Assessment Resources.

Costa, P. T., Jr., McCrae, R. R., \& Dye, D. A. 1991. Facet scales for agreeableness and conscientiousness: A revision of the NEO Personality Inventory. Personality and Individual Differences, 12: 887-898.

Deary, I. J., Blenkin, H., Agius, R. M., Endler, N. S., Zealley, H., \& Wood, R. 1996. Models of Job-Related Stress and Personal Achievement Among Consultant Doctors. British Journal of Psychology, 87: 3-29.

Denissen, J. J. A. \& Penke, L. 2008. Motivational Individual Reaction Norms Underlying the Five-Factor Model of Personality: First Steps toward A Theory-Based
Conceptual Framework. Journal of Research in Personality, 42: 1285-1302.

Dorn, L., \& Matthews, G. 1992. Two Further Studies of Personality Correlates of Driver Stress. Personality and Individual Differences, 13: 949-951.

Evan, G. W., \& Johnson, D. 2000. Stress and Open Office Noise. Journal of Applied Psychology, 85: 779-783

Fatimah, H., Dharmawan, A. H., Sunarti, E., \& Affandi, M. J. 2015. Pengaruh Faktor Karakteristik Individu dan Budaya Organisasi terhadap Keterikatan Pegawai Generasi X dan Y. Jurnal Aplikasi Manajemen, 13(3): 403-411.

Goldberg, L.R. 1992. The development of markers for the Big-Five factor structure. Psychological Assessment, 4: 26-42.

Goldberg, L. R., Johnson, J. A., Eber, H. W., Hogan, R., Ashton, M. C., \& Cloninger, C. R. 2006. The International Personality Item Pool and the future of public-domain personality measures. Journal of Research in Personality, 40: 84-96.

Hair, Joseph. F., Black, William, C., Babin, Barry, J., Anderson, Rolph, E. (7th Eds.). 2010. Multivariate Data Analysis. New Jersey: Pearson Education.

Hardiyanti, Ranny. 2013. Burnout Ditinjau dari Big Five Factors Personality Pada Karyawan Kantos Pos Malang. Jurnal IImiah Psikologi Terapan, 1(2): 343-360.

Hart, K.A. 2006. Generations in the workplace: finding common ground, diakses pada 3 Juni 2017, dari laman www.mloonline.com.

Hussain, Asrar., \& Chaman, Seemab. 2016. Combined Effect of Personality Traits and Collectivistic Culture on Employee's Job Stress in Banking Sector. International Journal of Arts \& Sciences, 9(3): 311-324.

Jenkins, J. 2007. Leading the Four Generations at Work, downloaded $4^{\text {th }}$ June 2017, from http://www.amanet.org/movingahead/editorial.cfm?Ed $=452$.

Jorgensen, B. 2003. Baby boomers, Gen $X$ ad Gen Y? Policy Implication for Defense Forces in The Modern Era. Foresight, 5(4): 41-49.

Kraus, Markus. 2017. Comparing Generation X and Generation $Y$ on their preferred emotional leadership style.Journal of Applied Leadership and Management,5: 62-75.

Kupperschmidt, B.R. 2000. Multigeneration Employees: Strategies for Effective 
Management. The Health Care Manager, 19(1): 65-76.

Lingard, Helen. 2003. The impact of individual and job characteristics on 'burnout' among civil engineers in Australia and the implications for employee turnover. Construction Management \& Economics, 21(1):69-80.

Lyons, Sean., \& Kuron, Lisa. 2014. Generational Differences in the Workplace: A Review of The Evidance and Direction of Future Research. Journal of Organizational Behavior, 35: 139-157.

McAdams, D. P., \& Pals, J. L. 2006. A New Big Five: Fundamental Principles for an Integrative Science of Personality. American Psychologist 61: 204-217.

Parker, D, F., \& DeCotiis, T, A. 1983. Organizational Determinants of Job Stress. Organizational Behavior and Human Performance, 32(2): 160-177.

Posthuma, R. A., \& Campion, M. A. 2009. Age stereotypes in the workplace: Common stereotypes, moderators, and future research directions. Journal of Management, 35: 158-188.

Rajput, N., Preeti, M., Ritu, B., and Monika, G. 2013. Managing Multigenerational Workforce Challenge for Millennium Managers. International Journal of Marketing and Technology, 3(2): 132149.

Ramdhani, Neila. 2012. Adaptasi Budaya dan inventori Big Five. Jurnal Psikologi, 39(2): 189-207.

Robbins, S. P. 2004. Teori Organisasi, Struktur, Desain, dan Aplikasi. (Alih Bahasa: Tim Indeks). New Jersey: Prentice Hall.

Roberts, B. W., Walton, K. E., \& Viechtbauer, W. 2006. Patterns of mean-level change in personality traits across the life course: A meta-analysis of longitudinal studies. Psychological Bulletin, 132: 3-27.

Robinson, S. L., Kraatz, M. S., Rousseau, D. M. 1994. Changing Obligation and the Psychological Contract: A Longitudinal Study. Academy Of Management Journal, 37(1): 137-152.

Rosen, B., \& Jerdee, T. H. 1976. The nature of job-related age stereotypes. Journal of Applied Psychology, 61: 180-183.

Sekaran, Uma (4th Eds.). 2003. Research Method for Business: A Skill Building Approach. New York: John Wiley \& Sons, Inc.

Schewe, C. D., \& Noble, S. M. 2000. Market Segmentation by Cohorts: The Value and Validity of Cohorts in America and
Abroad. Journal of Marketing Management, 16(1-3): 129-142.

Schultz, D. P., \& Schultz, S. E. 1994. Psychology and Work Today. New York: McMillan Publishing Company, Inc.

Shaifa, Demira., \& Supriyadi. 2013. Hubungan Dimensi Kepribadian The Big Five Personality dengan Penyesuaian Diri Mahasiswa Asing di Universitas Udayana. Jurnal Psikologi Udayana, 1(1): 72-83.

Sheridan, C. L., \& Radmacher, S. A. 1992. Health psychology: Challenging The Biomedical Model. Singapore: John Wiley and Sons, Inc.

Smola, K, W., \& Sutton, C, D. 2002. Generational Differences: Revisiting Generational Work Values For The New Millenium. Journal of Organizational Behavior, 23(SPI): 363382.

Truxillo, D. M., McCune, E. A., Bertolino, M., \& Fraccalori, F. 2012. Perception of Older Versus Younger Workers in Terms of Big Five Personality, Cognitive Ability, and Job Performance. Journal of Applied Social Psychology, 42(11): 2607-2639.

Tolbize, Anick. 2008. Generational Differences in the Workplace. Downloaded at $1^{\text {st }}$ June 2017, from https://rtc3.umn.edu/docs/2_18_Gen_diff workplace.pdf

Twenge, J. M., \& Campbell, S. M. 2008. Generational Differences in Psychological Traits and Their Impact in The Workplace. Journal of Managerial Psychology, 23(8): 862-877.

Watson, D. \& Clark, L.A. 1992. On Traits and Temperament: General and Specific Factors of Emotional Experience and Their Relation to The Five-Factor Model. Journal of Personality, 60(2): 441-476

Watson, D., \& Hubbard, B. 1996. Adaptational Style and Dispositional Structure: Coping In The Context Of The Five-Factor Model. Journal of Personality, 64: 737-774.

Wong, M., Gardiner, E., Lang, W., \& Coulon, L. 2008. Generational Differences in Personality and Motivation: Do They Exist and What Are the Implication for the Workplce?. Journal of Managerial Psychology, 23(8): 878-890.

Wood, D., \& Roberts, B. W. 2006. The effect of age and role information on expectations for Big Five personality traits. Personality and Social Psychology Bulletin, 32: 1482-1496. 
Yigit, Sema.,\& Aksay, Kadir. 2015. A Comparison between Generation X and Generation $Y$ in Terms of Individual Innovativeness Behavior: The Case of Turkish Health Professionals. International Journal of Business Administration, 6(2): 106-117.

Yu, H. C., \& Miller, P. 2003. The Generation Gap and Cultural Influence-A Taiwan Empirical Investigation. Cross Cultural Management, 10(3): 23-41.

Zellars, K. L., Perrewe, P. L., \& Hochwarter, W. A. 2000. Burnout In Health Care: The Role Of The Five Factors of Personality. Journal Of Applied Social Psychology, 30(8): 1570-1598.

Zemke, R., Raines, C., \&Filipezak, B. 2000. Generation at work: Managing the Clash of Veterans, Boomers, Xers, and Nexters in Your Workplace. New York: American Management Ascociation 